\title{
Índice del número 14
}

\section{Páginas Preliminares}

Presentación general del número

Pág. 1-2

Graciela Tonon

Reconocimiento a los evaluadores del número 14

Pág. 3

Graciela Tonon

\section{Sección Ensayos}

Hacia una deconstrucción de la unión mujer-madre

Pág. 4-22

María Laura Giallorenzi

Aproximaciones teóricas y metodológicas en torno al comercio sexual con niños, niñas y adolescentes en Girardot, Cundinamarca

Pág. 23-46

Andrés Francisco Olivar Rojas y Yeimy Karina Rojas Bonilla

Castas: Identidades que atraviesan fronteras

Pág. 47-65

Nora Lucía Ibarra

La perplejidad del sentido

Paula Muriel Belmes

Pág. 66-78

En torno a los antecedentes de la distribución de la tierra en el México

Central. Cuestión social e ideología liberal. 1906-1909

Pág. 79-102

Mariano Enrique Torres

\section{Sección Artículos}

Propuesta de zonificación de usos del suelo en el paraje "Las Toscas", partido de Lobería, provincia de Buenos Aires, en los inicios del siglo XXI Camila Rodríguez

\section{Sección Aportes de Estudiantes}

Una reflexión sobre la multidimensionalidad de la desigualdad social Martín Carlomagno

Impactos de las tecnologías en la niñez

Alejandra Tourn

Pág. 103-127

\section{Sección Reseña y Rescate de Libros}

Cartografías socio-estatales y subjetividades. Un recorrido sobre

Pág. 138-141 programas sociales en la contemporaneidad María Pía Castro Ruiz

Desigualdad en la academia: mujeres en las ciencias sociales peruanas María Rosa Luján Limardo

Pág. 128-132

Pág. 133-137 


\section{Sección Debates Internacionales}

Introducción de Sección

Pág. 146-149

Lía Rodríguez de la Vega

Pág. 150-155

Silvana Barrios

África y la dinámica del coronavirus

Ana María Sánchez

Pág. 156-161

\section{Sección Panorama Social}

Introducción de Sección

Pág. 162

Francisco Lavolpe

El rol de los estados nacionales en el marco de la pandemia de COVID19. Una mirada a nuestra América Latina

Francisco Lavolpe

La gobernabilidad en tiempos del COVID 19: una mirada desde Europa y Pág. 168-174 Sudamérica

Alejandro Di Giacomo

Pág. 163-167 